\title{
Ecto-5'-nucleotidase expression is associated with the progression of renal cell carcinoma
}

\author{
YI YU ${ }^{1}$, WEI WANG ${ }^{1}$, LEI SONG ${ }^{2,3}$, WENTAO HU ${ }^{2}, \mathrm{CHI} \mathrm{DONG}^{4}$, \\ HAILONG PEI ${ }^{2}$, GUANGMING ZHOU ${ }^{2}$ and ZHONGJIN YUE ${ }^{1}$
}

\begin{abstract}
${ }^{1}$ Department of Urological Surgery, Key Laboratory of Urinary Diseases of Gansu Province, Second Hospital of Lanzhou University, Lanzhou, Gansu 730030; ${ }^{2}$ Department of Space Radiobiology, Key Laboratory of Heavy Ion Radiation Biology and Medicine, Institute of Modern Physics, Chinese Academy of Sciences, Lanzhou, Gansu 730000; ${ }^{3}$ Medical College, Northwest University for Nationalities, Lanzhou, Gansu 730030;

${ }^{4}$ Department of Pathology, Second Hospital of Lanzhou University, Lanzhou, Gansu 730000, P.R. China
\end{abstract}

Received June 12, 2014; Accepted February 27, 2015

DOI: $10.3892 / \mathrm{ol} .2015 .3138$

\begin{abstract}
Renal cell carcinoma (RCC) is a common tissue tumor that occurs across all age groups and has become one of the types of cancer with the fastest increasing incidence. Due to the resistance of RCC chemo- and radiotherapy, surgery is the only currently effective treatment. Therefore, specific markers for the diagnosis and prognosis of RCC are expected to result in novel methods of treatment. Ecto-5'-nucleotidase, also termed cluster of differentiation (CD)73, is a protein that is activated in several types of aggressive cancer and may promote cancer progression. CD73 was examined in the present study to determine the association between the protein and RCC. The expression levels of CD73 in 159 RCC tissue sections and 30 paratumorous normal renal tissue samples obtained from 235 patients that underwent nephrectomy were examined by immunohistochemical staining. By contrast, the expression level of P-glycoprotein (P-gp), a potential prognostic factor in RCC, was also examined in 85 RCC and 13 normal tissue samples. Intense CD73 expression was identified in 75 out of 159 RCC cell membranes compared with normal renal tissues. In contrast, there was high P-gp expression in the blood vessels of 42 out of 85 RCC tissues and there was no significant difference between the P-gp expression identified in RCC cells (34 out of 85) and the cell membrane of normal renal cells ( 2 out of 13). The expression level of CD73 in RCC cells was significantly associated with tumor type, tumor node metastasis (TNM) stage, and tumor grade. However, the expression of P-gp in RCC cells was only associated with
\end{abstract}

Correspondence to: Dr Zhongjin Yue, Department of Urological Surgery, Key Laboratory of Urinary Diseases of Gansu Province, Second Hospital of Lanzhou University, 82 Cuiyingmen Road, Lanzhou, Gansu 730030, P.R. China

E-mail: yuezhongjin@sina.com

Key words: renal cell carcinoma, CD73, P-glycoprotein, tumor progression, prognosis the TNM stage and tumor grade. Using a multivariable Cox regression analysis, it was found that the median survival rate of RCC patients with intense CD73 expression in RCC cells was $62.06 \pm 5.35$ months, which was drastically shorter compared with rare CD73 expression (103.72 \pm 3.67 months). In conclusion, the expression level of CD73 is significantly associated with RCC tumor progression and may serve as a favorable marker for the diagnosis and prognosis of RCC, in addition to being a therapeutic target for the treatment of RCC.

\section{Introduction}

Renal cell carcinoma (RCC) is the most common malignant kidney neoplasm that occurs across all age groups, and the disease accounts for $\sim 3 \%$ of all cancers worldwide (1). RCC is the seventh leading cause of cancer in the USA, resulting in $\sim 54,390$ novel cancer cases and $\sim 14,000$ mortalities each year in the USA (2). In China, RCC has become one of the cancer types with the fastest increasing incidence, increasing at an annual rate of $6 \%$ (3). Improvements in diagnostic imaging technology have enabled more RCC cases to be diagnosed at an early stage and the five-year survival rate of patients with RCC has reached 67\% (4). However, as RCC is insensitive to chemo- and radiotherapy, advanced RCC with systemic metastasis demonstrates a poorer prognosis and the five-year survival rate is $<10 \%$ (5). RCC comprises several histological subtypes and $\sim 75 \%$ of RCC lesions are clear cell carcinoma, which is associated with the worst prognosis (6). Therefore, specific markers for clear cell RCC are required to improve the early diagnosis and targeted therapy of RCC, and for patients to eventually demonstrate a good prognosis and outcome.

$\mathrm{P}$-glycoprotein $(\mathrm{P}-\mathrm{gp})$ is a drug efflux pump that is widely associated with the chemoresistance of a variety of tumors $(7,8)$. The expression of P-gp has been reported in untreated RCC $(9,10)$ and is strongly associated with a differentiated RCC tumor phenotype (11-13). However, the use of P-gp as a specific biomarker for RCC remains controversial. Thus, additional specific biomarkers for RCC are required.

Ecto-5'-nucleotidase, also termed cluster of differentiation (CD)73, is a glycosyl phosphatidylinositol-linked membrane 
protein found on the surface of a variety of cell types (14). CD73 was initially identified as a cell surface antigen that was specific to hematopoietic stem cells and functioned in a number of physiological processes in various normal human tissues, including hypoxic adaptation, ischemic preconditioning and inflammation (15-17). CD73 is reportedly activated in aggressive breast cancer, gastric and pancreatic cancers and lymphoma, and may be used as a prognostic marker for these tumors $(18,19)$. The protective role of CD73 in renal ischemia (20) and the absence of tubuloglomerular feedback responses in CD73-deficient mice (14) have indicated the important role of CD73 in the function of renal tissue. Furthermore, abnormal expression of CD73 may be associated with the progression of RCC. However, the association between CD73 expression and $\mathrm{RCC}$ is unclear. The present study aimed to investigate the expression of CD73 and P-gp in clear cell $\mathrm{RCC}$ and to assess their potential significance for the clinical diagnosis and prognosis of RCC.

\section{Patients and methods}

Patients. Pathological tissues were collected from patients with RCC who had undergone surgery between January 2004 and July 2012 at the Second Hospital of Lanzhou University (Lanzhou, China). A total of 235 patients aged between 35 and 87 years of age (median, 58 years) that were diagnosed with RCC and 30 transitional-normal tissues collected from certain patients were selected for the present retrospective study. Pathological confirmation was conducted on standard sections stained with hematoxylin and eosin according to the World Health Organization guidelines (21). Clinical follow-up data were available for the majority of patients. The medical records of these patients were reviewed and the demographic characteristics, date of diagnosis, date of surgery, resection margin status, tumor stage, tumor size, tumor differentiation and five-year survival rates were retrieved. The tumor stage was assessed according to the pathological tumor-node-metastasis (TNM) staging system based on the tumor size and progression status, involvement of the lymph nodes, presence of distant metastasis and tumor differentiation, according to the medical records. In addition to these characteristics, the mortality reports were obtained by maintaining regular contact with close relatives of the enrolled patients. All clinical information was independently confirmed. This study was approved by the ethics committee of the Second Hospital of Lanzhou University and written informed consent was obtained from the families of the patients.

Immunohistochemical assay. The expression levels of CD73 and P-gp were determined using a two-step immunohistochemical assay procedure. Briefly, P-gp was detected using a PV-6000 Polymer Detection System (Zhongshan Golden Bridge Biotechnology, Co., Ltd., Beijing, China). Surgically resected specimens were fixed in $10 \%$ formalin and cut into $4-\mu \mathrm{m}$ thick slices. The sections were subsequently mounted on Superfrost Plus slides (Zhongshan Golden Bridge Biotechnology, Co., Ltd.), de-waxed with xylene and gradually hydrated. Antigen retrieval was then achieved by pressure-cooking the samples in $0.01 \mathrm{M}$ citrate buffer $(\mathrm{pH} 6.0)$ for $2 \mathrm{~min}$, cooling to room temperature, washing with PBS
Table I. Percentage and intensity grade of staining.

\begin{tabular}{lcc}
\hline Level & $\begin{array}{c}\text { Percentage of intensively } \\
\text { stained cells, } \%\end{array}$ & $\begin{array}{c}\text { Intensity } \\
\text { of staining }\end{array}$ \\
\hline 0 & 0 & Low \\
1 & $<25$ & Weak \\
2 & $25 \leq x<50$ & Moderate \\
3 & $50 \leq x<100$ & Strong \\
\hline
\end{tabular}

and incubating in 3\% hydrogen peroxide for $10 \mathrm{~min}$. Monoclonal rabbit anti-human CD73 (cat. no. ab115289; Abcam, Cambridge, MA, USA) and monoclonal mouse anti-human P-gp (cat. no. zm0189; Zhongshan Golden Bridge Biotechnology, Co., Ltd.) antibodies were used as primary antibodies at a 1:200 dilution, with $50 \mu \mathrm{l}$ of solution being used for each section. Mouse IgG (Abcam) was used as a control. The sections were incubated with the primary antibodies for $2 \mathrm{~h}$ at $37^{\circ} \mathrm{C}$, washed with PBS, incubated with horseradish peroxidase-conjugated polyclonal sheep anti-rabbit (cat. no. pv6000) or anti-mouse (cat. no. pv6000) IgG secondary antibodies (Zhongshan Golden Bridge Biotechnology, Co., Ltd.) for $30 \mathrm{~min}$ at $37^{\circ} \mathrm{C}$ and then washed three times in $0.1 \%$ Tween-20 (Zhongshan Golden Bridge Biotechnology, Co., Ltd.). Subsequently, the sections were developed with diaminobenzidine tetrahydrochloride (DAB) and selected samples were counterstained with hematoxylin. The immunohistochemical assays were performed within seven days of section preparation. To prevent antigen degradation, the sections were stored at $4^{\circ} \mathrm{C}$ prior to analysis.

Immunostaining evaluation. The results from the immunohistochemical staining of tissue slides were independently evaluated by two pathologists in a double-blind process. Immunohistochemical staining of the tissue slides indicated whether the stained CD73 and P-gp proteins were located in the cytoplasm, cell membrane or vascular wall. A semi-quantitative scoring system was developed (Table I) based on the staining intensity, with low, weak, moderate and strong staining being classified as levels $0,1,2$ and 3, respectively, and the percentage of cells with intense staining, with levels $0,1,2$ and 3 being defined as no cells positively stained, $<25 \%$ cells stained, $26-50 \%$ cells stained and $>50 \%$ cells stained, respectively. For each slide, three fields were evaluated. In addition, the slides were re-evaluated, classified according to the resulting scores, and the highest score was used for subsequent analyses.

Statistical analysis. The data were analyzed using SPSS software, version 19.0 (IBM, Armonk, NY, USA). Categorical data were reported as counts and percentages. Fisher's exact test and the $\chi^{2}$ test for trends were used to assess the significance of associations between the expression of CD73 or P-gp. Associations between clinicopathological parameters were tested using the Mann-Whitney $U$ test and the Kruskal-Wallis $\mathrm{H}$ test. Univariate survival analysis was performed according to the Kaplan-Meier method and differences in survival curves were assessed. Multivariate survival analysis was performed on all important parameters (14) using Cox's regression model. In 
Table II. Immunohistochemical staining properties of CD73 and P-gp for two kinds of kidney cancer and transitional-normal tissues.

A, CD73 expression and location in different renal cell carcinoma

\begin{tabular}{lccccrr}
\hline Location & $\begin{array}{c}\text { Expression } \\
\text { level }\end{array}$ & $\begin{array}{c}\text { Normal renal } \\
\text { tissue, } \mathrm{n}(\%)\end{array}$ & $\begin{array}{c}\text { Clear cell } \\
\text { RCC, n }(\%)\end{array}$ & $\begin{array}{c}\text { Uroepithelial } \\
\text { carcinoma, n (\%) }\end{array}$ & $\chi^{2}$ & P-value \\
\hline Cell membrane & Rare & $30(100.00)$ & $64(51.61)$ & $20(57.14)$ & 22.568 & 0.000 \\
& Intensive & $0(0.00)$ & $60(48.39)^{\mathrm{a}}$ & $15(42.86)^{\mathrm{a}}$ & & \\
Vascular wall & Rare & $26(86.67)$ & $110(88.71)$ & $35(100.00)$ & 4.989 & 0.074 \\
& Intensive & $4(13.33)$ & $14(11.29)$ & $0(0.00)$ & & \\
\hline
\end{tabular}

B, P-gp expression and location

\begin{tabular}{|c|c|c|c|c|c|c|}
\hline Location & $\begin{array}{l}\text { Expression } \\
\text { level }\end{array}$ & $\begin{array}{l}\text { Normal renal } \\
\text { tissue, n (\%) }\end{array}$ & $\begin{array}{c}\text { Clear cell } \\
\text { RCC }, \mathrm{n}(\%)\end{array}$ & $\begin{array}{c}\text { Uroepithelial } \\
\text { carcinoma, n (\%) }\end{array}$ & $\chi^{2}$ & $\mathrm{P}$-value \\
\hline \multirow[t]{2}{*}{ Cell membrane } & Absent & $11(84.6)$ & $39(65.0)$ & $12(48.0)$ & \multirow[t]{2}{*}{4.72} & \multirow[t]{2}{*}{0.095} \\
\hline & Intensive & $2(15.4)$ & $21(35.0)$ & $13(52.0)$ & & \\
\hline \multirow[t]{2}{*}{ Vascular wall } & Absent & $13(100.0)$ & $27(45.0)$ & $16(64.0)$ & \multirow[t]{2}{*}{16.30} & \multirow[t]{2}{*}{$0.000^{\mathrm{b}}$} \\
\hline & Intensive & $0(0.0)$ & $33(55.0)$ & $9(36.0)$ & & \\
\hline
\end{tabular}

${ }^{\mathrm{a}} \mathrm{P}<0.05$ between normal renal cells and different $\mathrm{RCC},{ }^{\mathrm{b}} \mathrm{P}<0.05$ between normal renal cells and different RCC. CD 73 , cluster of differentiation 73; P-gp, P-glycoprotein; RCC, renal cell carcinoma.

a visual evaluation of survival plots, no violation of proportional hazards was observed. Results are expressed as the mean \pm standard deviation. $\mathrm{P}<0.05$ was considered to indicate a statistically significantly difference.

\section{Results}

Patients. A total of 235 patients were included in the present study, which used the intact data from 205 RCC tissues, comprising 157 clear cell cancer and 48 urothelial carcinoma tissues, and 30 normal renal tissues. The patients ranged in age between 35 and 87 years $(58.1 \pm 5.2$ years) and the male to female ratio was 137:98. The mean tumor size was $7.6 \pm 3.2 \mathrm{~cm}$. A total of 89 RCC patients possessed lesions classified as stage I, 78 were classified as stage II, 33 were classified as stage III and 5 were classified as stage IV. The median follow-up time was 78 months (range, 1-118 months) and a total of 14 patients $(6.83 \%)$ succumbed to the disease.

Expression of CD73 and P-gp in RCC and normal renal tissue samples. The analysis of CD73 expression was performed in 159 tumor samples, consisting of 124 clear cell RCC and 35 uroepithelium cell carcinoma tissues, and 30 paratumorous normal renal tissue samples (Table II). CD73 expression was low in normal renal cells (Fig. 1A). In RCC tissues, CD73 expression was most frequently observed in the cell membrane and cytoplasm (Fig. 2), whereas little signal was observed in the vascular smooth muscle and leukomonocytes (Fig. 3). The majority of samples from RCC patients exhibited intense CD73 staining (75 out of 159; Table IIA), and $48.39 \%$ (60 out of 124) of clear cell RCC samples and $42.86 \%$
(15 out of 35) of uroepithelial cell carcinoma samples exhibited intense CD73 staining. In addition, CD73 expression in clear cell RCC and uroepithelial cell carcinoma was markedly increased compared with the expression in normal renal cells $(\mathrm{P}<0.001$ and $\mathrm{P}=0.001$, respectively; Table IIA). In addition, there was a high expression of CD73 in the vascular wall in 4 out of 30 normal tissues and 14 out of 159 tumor tissues (Table IIA) but the difference was not significant $(\mathrm{P}=0.074)$. $\mathrm{P}$-gp protein expression, determined in 85 tumors and 13 surrounding normal renal tissues (Table IIB), was mainly observed in the blood vessels of tumor tissues (42 out of 85) in cytomembrane and cytoplasmic compartments (Fig. 4). P-gp expression was also observed in the glomerulus, proximal convoluted tubule and lymphocytes in tumors (Fig. 5). The P-gp expression in the RCC blood vessels was significantly increased compared with the expression in the blood vessels in normal tissue $(\mathrm{P}<0.001$; Table $\mathrm{V})$.

Cells were classified into three levels according to the percentage and intensity of CD73 staining (Table III). In the group with clear cell RCC, $43.3 \%$ (68 out of 157) scored as Level 1, 4.5\% (7 out of 157) as Level 2 and 3.8\% (6 out of 157) as Level 3. By contrast, in uroepithelial carcinoma cases, $35.4 \%$ (17 out of 48) scored as Level 1,8.3\% (4 out of 48) as Level 2 and $6.3 \%$ (3 out of 48) as Level 3. The classification of patients based on the percentage and intensity of P-gp staining was examined (Table IV). In the group of patients with clear cell RCC, $25.3 \%$ (19 out of 157) scored as Level 1, 10.7\% (8 out of 157) as Level 2 and 4.0\% (3 out of 157) as Level 3. In addition, 37.9\% (11 out of 48) of the uroepithelial carcinoma cases scored as Level 1, 10.3\% (3 out of 48) as Level 2 and $0 \%$ as Level 3. Therefore, the expression level of CD73 is more strongly associated with the classification of RCC than the expression of P-gp. 
Table III. CD73 expression in RCC and its association with clinicopathological factors.

\begin{tabular}{|c|c|c|c|c|c|c|c|}
\hline \multirow[b]{2}{*}{ Variable } & \multirow{2}{*}{$\begin{array}{l}\text { Number of } \\
\text { samples, } \mathrm{n}\end{array}$} & \multirow{2}{*}{$\begin{array}{l}\text { Low expression, } \\
\mathrm{n}(\%)\end{array}$} & \multicolumn{3}{|c|}{ Intensive expression, $\mathrm{n}(\%)$} & \multirow[b]{2}{*}{$\chi^{2}$} & \multirow[b]{2}{*}{ P-value } \\
\hline & & & Level 1 & Level 2 & Level 3 & & \\
\hline \multicolumn{8}{|l|}{ Gender } \\
\hline Male & 119 & $73(61.3)$ & $42(35.3)$ & $3(2.5)$ & $1(0.8)$ & 0.677 & 0.498 \\
\hline Female & 70 & $41(58.6)$ & $21(30.0)$ & $6(8.6)$ & $2(2.9)$ & & \\
\hline \multicolumn{8}{|l|}{ Tumor type } \\
\hline Normal & 30 & $30(100.0)$ & $0(0.0)$ & $0(0.0)$ & $0(0.0)$ & 30.184 & 0.000 \\
\hline Clear cell RCC & 157 & $76(48.4)$ & $68(43.3)$ & $7(4.5)$ & $6(3.8)$ & & \\
\hline Urothelium carcinoma & 48 & $24(50.0)$ & $17(35.4)$ & $4(8.3)$ & $3(6.3)$ & & \\
\hline \multicolumn{8}{|l|}{ TNM stage } \\
\hline T1N0M0 & 73 & $35(47.9)$ & $35(47.9)$ & $2(2.7)$ & $1(1.4)$ & 12.186 & 0.002 \\
\hline T2N0M0 & 70 & $45(64.3)$ & $21(30.0)$ & $1(1.4)$ & $3(4.3)$ & & \\
\hline T3N0M0 & 28 & $8(28.6)$ & $14(50.0)$ & $5(17.9)$ & $1(3.6)$ & & \\
\hline T4N0M0 N+M ${ }^{+}$ & 2 & $0(0.0)$ & $1(50.0)$ & $1(50.0)$ & $0(0.0)$ & & \\
\hline \multicolumn{8}{|l|}{ Tumor grade } \\
\hline 1 & 49 & $33(67.3)$ & $12(24.5)$ & $4(8.2)$ & $0(0.0)$ & 12.821 & 0.002 \\
\hline 2 & 95 & $48(50.5)$ & $43(45.3)$ & $1(1.1)$ & $3(3.2)$ & & \\
\hline 3 & 53 & $17(32.1)$ & $28(52.8)$ & $5(9.4)$ & $3(5.7)$ & & \\
\hline
\end{tabular}

RCC, renal cell carcinoma; TNM, tumor-node-metastasis; $\mathrm{N}^{+}$, lymph node involvement; $\mathrm{M}^{+}$, presence of metastasis.

Table IV. P-glycoprotein expression in RCC and its association with clinicopathological factors.

\begin{tabular}{|c|c|c|c|c|c|c|c|}
\hline \multirow[b]{2}{*}{ Variable } & \multirow{2}{*}{$\begin{array}{l}\text { Number of } \\
\text { samples, } \mathrm{n}\end{array}$} & \multirow{2}{*}{$\begin{array}{l}\text { Low expression, } \\
\mathrm{n}(\%)\end{array}$} & \multicolumn{3}{|c|}{ Intensive expression, n (\%) } & \multirow[b]{2}{*}{$\chi^{2}$} & \multirow[b]{2}{*}{ P-value } \\
\hline & & & Level 1 & Level 2 & Level 3 & & \\
\hline \multicolumn{8}{|l|}{ Gender } \\
\hline Male & 63 & $35(55.6)$ & $20(31.7)$ & $7(11.1)$ & $1(1.6)$ & 0.232 & 0.816 \\
\hline Female & 42 & $25(59.5)$ & $11(26.2)$ & $4(9.5)$ & $2(4.8)$ & & \\
\hline \multicolumn{8}{|l|}{ Tumor type } \\
\hline Normal & 13 & $11(84.6)$ & $0(0.0)$ & $2(15.4)$ & $0(0.0)$ & 8.616 & 0.196 \\
\hline Clear cell RCC & 75 & $45(60.0)$ & $19(25.3)$ & $8(10.7)$ & $3(4.0)$ & & \\
\hline Urothelium carcinoma & 29 & $15(51.7)$ & $11(37.9)$ & $3(10.3)$ & $0(0.0)$ & & \\
\hline \multicolumn{8}{|l|}{ TNM stage } \\
\hline T1N0M0 & 42 & $29(69.0)$ & $10(23.8)$ & $3(7.1)$ & $0(0.0)$ & 8.463 & 0.015 \\
\hline T2N0M0 & 33 & $19(57.6)$ & $11(33.3)$ & $1(3.0)$ & $2(6.1)$ & & \\
\hline T3N0M0 & 18 & $6(33.3)$ & $6(33.3)$ & $5(27.8)$ & $1(5.6)$ & & \\
\hline T4N0M0 N+M ${ }^{+}$ & 2 & $2(100.0)$ & $0(0.0)$ & $0(0.0)$ & $0(0.0)$ & & \\
\hline \multicolumn{8}{|l|}{ Tumor grade } \\
\hline 1 & 25 & $20(80.0)$ & $4(16.0)$ & $1(4.0)$ & $0(0.0)$ & 7.282 & 0.026 \\
\hline 2 & 38 & $20(52.6)$ & $12(31.6)$ & $5(13.2)$ & $1(2.6)$ & & \\
\hline 3 & 42 & $20(47.6)$ & $15(35.7)$ & $5(11.9)$ & $2(4.8)$ & & \\
\hline
\end{tabular}

RCC, renal cell carcinoma; TNM, tumor-node-metastasis; $\mathrm{N}^{+}$, lymph node involvement; $\mathrm{M}^{+}$, presence of metastasis.

Association between the expression of CD73 and P-gp and clinicopathological features. The present analyses revealed that clinicopathological parameters, including the tumor type and an advanced tumor stage, were significantly associated with CD73 expression in RCC tissue cells. CD73 expression was also associated with an increased tumor grade (Table III). CD73 was intensely expressed in $32.65 \%$ (16 out of 49 ) grade $1,49.47 \%$ (47 out of 95 ) 
Table V. Association of tumor specific characteristics with CD73 and P-gp expression in tumor blood vessel.

\begin{tabular}{|c|c|c|c|c|c|c|c|c|}
\hline \multirow[b]{2}{*}{ Variable } & \multicolumn{2}{|c|}{ CD73, n (\%) } & \multirow[b]{2}{*}{$\chi^{2}$} & \multirow[b]{2}{*}{ P-value } & \multicolumn{2}{|c|}{ P-gp, n (\%) } & \multirow[b]{2}{*}{$\chi^{2}$} & \multirow[b]{2}{*}{ P-value } \\
\hline & Low & Intensive & & & Low & Intensive & & \\
\hline \multicolumn{9}{|l|}{ Gender } \\
\hline Male & $113(90.4)$ & $12(9.6)$ & 1.323 & 0.250 & $34(53.13)$ & $30(46.88)$ & 0.000 & 0.994 \\
\hline Female & $74(94.9)$ & $4(5.1)$ & & & $23(54.76)$ & $19(45.24)$ & & \\
\hline \multicolumn{9}{|l|}{ Tumor type } \\
\hline Normal & $26(86.7)$ & $4(13.3)$ & 4.365 & 0.113 & $13(100.00)$ & $0(0.00)$ & 14.590 & 0.001 \\
\hline Clear cell RCC & $141(89.81)$ & $16(10.19)$ & & & $36(48.00)$ & $39(52.00)$ & & \\
\hline Urothelium carcinoma & $45(97.8)$ & $1(2.2)$ & & & $20(66.67)$ & $10(33.33)$ & & \\
\hline \multicolumn{9}{|l|}{ Stage } \\
\hline T1N0M0 & $61(85.9)$ & $10(14.1)$ & 4.261 & 0.235 & $19(45.24)$ & $23(54.76)$ & 3.226 & 0.358 \\
\hline T2NOM0 & $67(95.7)$ & $3(4.3)$ & & & $18(52.94)$ & $16(47.06)$ & & \\
\hline T3N0M0 & $25(89.3)$ & $3(10.7)$ & & & $11(61.11)$ & $7(38.90)$ & & \\
\hline T4N0M0-N+M+ & $2(100.0)$ & $0(0.0)$ & & & $2(100.00)$ & $0(0.00)$ & & \\
\hline \multicolumn{9}{|l|}{ Grade } \\
\hline 1 & $43(87.8)$ & $6(12.2)$ & 2.310 & 0.315 & $7(28.00)$ & $18(72.00)$ & 11.948 & 0.003 \\
\hline 2 & 87 (91.6) & $8(8.4)$ & & & $21(53.85)$ & $18(46.15)$ & & \\
\hline 3 & $49(96.1)$ & $2(3.9)$ & & & $30(71.43)$ & $12(28.57)$ & & \\
\hline
\end{tabular}

CD73, cluster of differentiation 73; P-gp, P-glycoprotein; RCC, renal cell carcinoma; TNM, tumor-node-metastasis; $\mathrm{N}^{+}$, lymph node involvement; $\mathrm{M}^{+}$, presence of metastasis.

Table VI. Multivariate Cox proportional hazards model of RCC.

\begin{tabular}{llll}
\hline Variable & HR & \multicolumn{1}{c}{$95 \% \mathrm{CI}$} & P-value \\
\hline Gender & 3.061 & $0.888-10.552$ & 0.076 \\
Age & 0.974 & $0.909-1.043$ & 0.453 \\
Type of tumor & 1.524 & $0.265-8.776$ & 0.637 \\
Pathological stage & 3.537 & $0.952-13.139$ & 0.059 \\
Histological grade & 3.929 & $1.098-14.062$ & 0.035 \\
Tumor size & 0.870 & $0.696-1.089$ & 0.224 \\
CD73 intensive & 3.989 & $1.089-14.611$ & 0.037 \\
P-gp intensive & 0.703 & $0.184-2.679$ & 0.605 \\
\hline
\end{tabular}

CD73, cluster of differentiation 73; P-gp, P-glycoprotein; HR, hazard ratio; CI, cluster of differentiation.

grade 2 and $67.92 \%$ (36 out of 53) grade 3 RCC tissue samples. Based on the TNM analysis, CD73 expression in RCC tissue cells was also found to be associated with tumor differentiation. The incidence of CD73 expression in RCC tissue cells was $52.05 \%$ (38 out of 73 ) and $35.71 \%$ ( 25 out of 70 ) in tumor stages T1N0M0 and T2N0M0, respectively. However, the incidence of $\mathrm{CD} 73$ expression was $71.43 \%$ (20 out of 28) and 100\% (2 out of 2) in tumor stages T3N0M0 and T4N0M0 $\mathrm{N}^{+} \mathrm{M}^{+}$, respectively. P-gp was found to be intensely expressed in $20 \%$ (5 out of 25 ) of grade 1 , $47.37 \%$ (18 out of 38 ) of grade 2 and $52.38 \%$ (22 out of 42 ) of grade 3 RCC tissues (Table IV).
Based on analysis of the TNM stage, P-gp expression in RCC tissue cells was also found to be associated with tumor differentiation (Table IV). The incidence of P-gp expression in RCC tissue cells was $30.95 \%$ (13 out of 42 ) and $42.42 \%$ (14 out of 33) in stages T1N0M0 and T2N0M0, respectively. However, the incidence of P-gp expression was $66.67 \%$ (12 out of 18 ) and $100 \%$ (2 out of 2 ) in stages T3N0M0 and T4N0M0 $\mathrm{N}^{+} \mathrm{M}^{+}$, respectively.

Association between the expression of CD73 and P-gp and the survival of RCC patients. At the end of the five-year follow-up, 14 out of 189 patients had succumbed to RCC. Therefore, the overall five-year survival rate of RCC patients was $80.60 \%$. The five-year survival rate of patients with intense CD73 expression in RCC tissue was $67.6 \%$, whereas the rate was $91.7 \%$ in patients with low CD73 expression $(\mathrm{P}<0.001)$. The median survival of RCC patients with intense CD73 expression was 78.00 months (range, 37.63-118.37 months; Table VII). The survival time of RCC patients with intense CD73 expression was $62.06 \pm 5.35$ months, which is markedly decreased compared with RCC patients with low CD73 expression (103.72 \pm 3.67 months; Table VII). A significant difference was observed between the survival rate of patients with intense CD73 expression compared with patients with low CD73 expression (Log-rank and Breslow tests, $\mathrm{P}<0.001$ ), indicating that the lack of CD73 expression is associated with an increased five-year survival rate in RCC patients.

The five-year survival rate of patients with intense P-gp expression was $44.1 \%$, which was not significantly increased compared with the five-year survival rate of $27.1 \%$ in patients with low P-gp expression (Log-rank analysis, $\mathrm{P}=0.957$; 
Table VII. Means and medians of survival time of renal cell carcinoma patients with rare and intensive CD73 expression.

\begin{tabular}{|c|c|c|c|c|c|c|c|c|}
\hline \multirow[b]{3}{*}{ CD73 } & \multicolumn{4}{|c|}{ Mean $^{a}$} & \multicolumn{4}{|c|}{ Median } \\
\hline & \multirow[b]{2}{*}{ Estimated } & \multirow[b]{2}{*}{ SE } & \multicolumn{2}{|c|}{$95 \%$ confidence interval } & \multirow[b]{2}{*}{ Estimated } & \multirow[b]{2}{*}{ SE } & \multicolumn{2}{|c|}{$95 \%$ confidence interval } \\
\hline & & & Lower bound & Upper bound & & & Lower bound & Upper bound \\
\hline Rare & 103.719 & 3.667 & 96.532 & 110.907 & & & & \\
\hline Intensive & 62.058 & 5.354 & 51.564 & 72.553 & 78.000 & 20.597 & 37.630 & 118.370 \\
\hline Overall & 89.460 & 4.021 & 81.579 & 97.342 & & & & \\
\hline
\end{tabular}

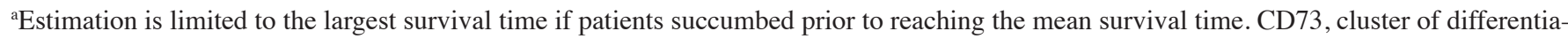
tion 73; SE, standard error.

Table VIII. Means and medians of survival time of RCC patients with rare and intensive P-gp expression.

\begin{tabular}{|c|c|c|c|c|c|c|c|c|}
\hline \multirow[b]{3}{*}{ P-gp } & \multicolumn{4}{|c|}{ Mean $^{\mathrm{a}}$} & \multicolumn{4}{|c|}{ Median } \\
\hline & \multirow[b]{2}{*}{ Estimated } & \multirow[b]{2}{*}{ SE } & \multicolumn{2}{|c|}{$95 \%$ confidence interval } & \multirow[b]{2}{*}{ Estimated } & \multirow[b]{2}{*}{ SE } & \multicolumn{2}{|c|}{$95 \%$ confidence interval } \\
\hline & & & Lower bound & Upper bound & & & Lower bound & Upper bound \\
\hline Rare & 46.608 & 4.352 & 38.079 & 55.137 & 45.000 & 4.734 & 35.722 & 54.278 \\
\hline Intensive & 47.408 & 5.582 & 36.468 & 58.348 & 47.000 & 3.656 & 39.834 & 54.166 \\
\hline Overall & 46.918 & 3.414 & 40.227 & 53.610 & 47.000 & 2.381 & 42.333 & 51.667 \\
\hline
\end{tabular}

${ }^{a}$ Estimation is limited to the largest survival time if patients succumbed prior to reaching the mean survival time. P-gp, P-glycoprotein; SE, standard error.
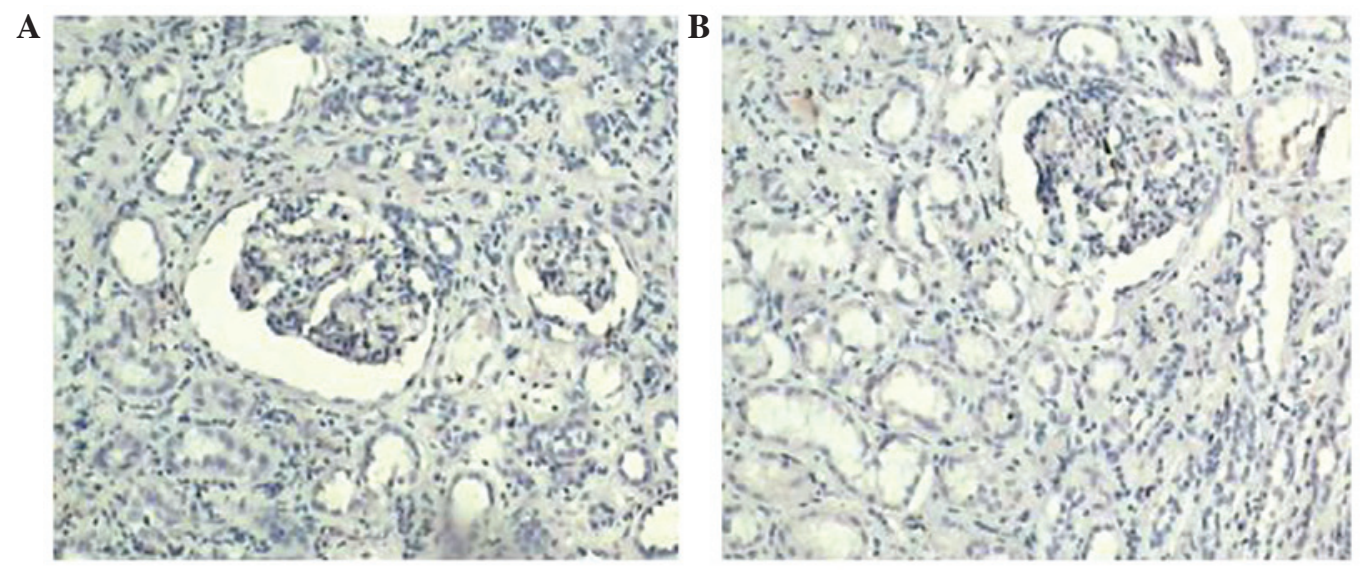

Figure 1. The low expression of CD73 and P-gp processed by immunohistochemistry in normal renal tissue. (A) CD73 (10x20); (B) P-gp (10x20).

Breslow test, $\mathrm{P}=0.795)$. Patients with RCC that exhibited intense P-gp expression demonstrated a median survival of 47.00 months (range, 39.83-54.17 months; Table VIII). The survival time of RCC patients with intense P-gp expression was $47.41 \pm 5.58$ months, which was similar to the survival time of RCC patients with low P-gp expression (46.61 \pm 4.35 months; Table VIII). No significant difference was observed in the survival of RCC patients based on P-gp expression (Log-rank and Breslow tests, $\mathrm{P}>0.05$ ).

In addition, multivariable Cox regression analysis, including gender, age, tumor type, TNM, tumor stage and grade, indicated that CD73 expression and histological grade, but not P-gp expression, were strongly associated with RCC prognosis (Table VI).

\section{Discussion}

In the present study, the expression levels of CD73 and P-gp were examined in RCC tumor and surrounding normal kidney tissues. An association was identified between intense CD73 expression and clear cell RCC, high TNM stage, high tumor grade and a low five-year survival rate, which indicates 

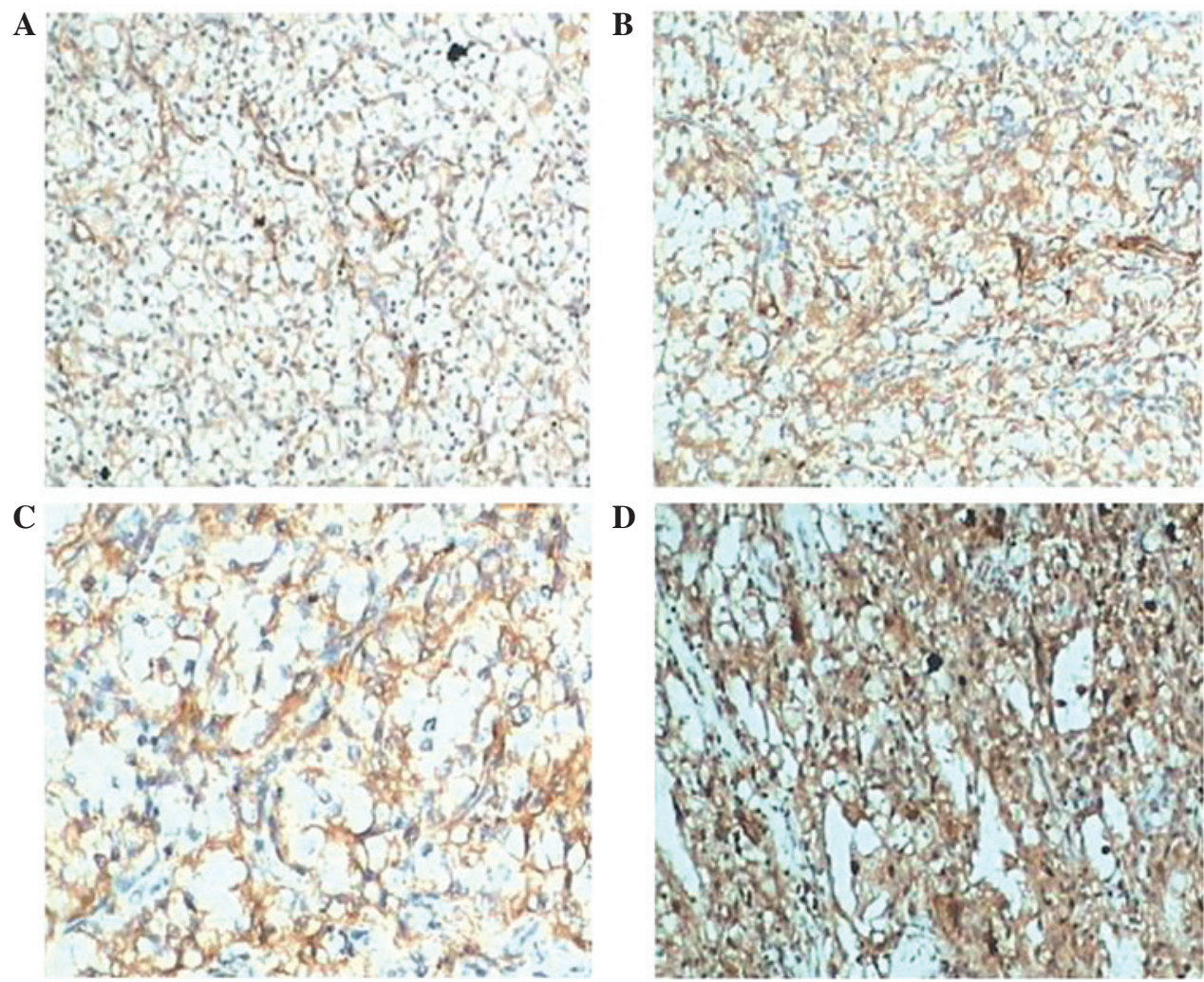

Figure 2. Expression of cluster of differentiation 73 in clear cell renal cell carcinoma. (A) Level 1 (magnification, x100); (B) Level 2 (magnification, x100); (C) Level 2 (magnification, x200); and (D) Level 3 (magnification, x100).

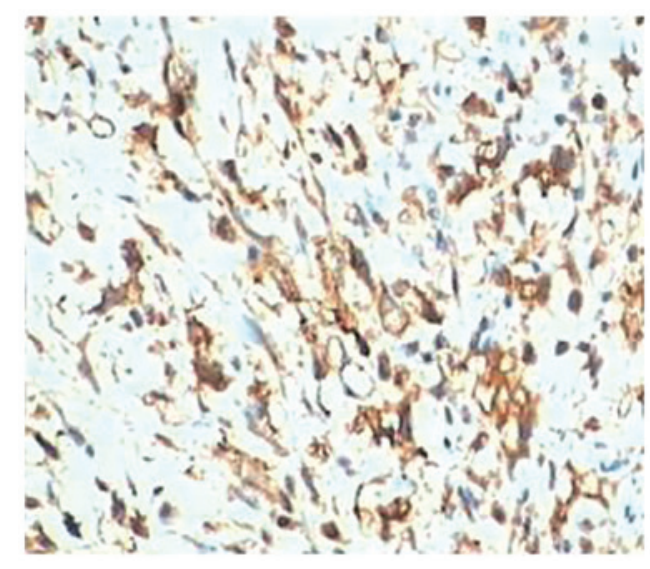

Figure 3. Cluster of differentiation 73 expression in vascular smooth muscle and leukomonocytes in renal cell carcinoma tissue (magnification, x200).

that CD73 is involved in the progression of clear cell RCC and may be used as a biomarker for the diagnosis and prognosis of RCC.

Previous studies have revealed that CD73 is applicable as a cell-surface marker of malignant tumors, including those in bladder cancer (22), leukemia (23), glioma (24), melanoma (25), and ovarian (26), colon, breast (7,24,27-29), thyroid (30), esophageal (31) and prostate cancers (32). However, to the best of our knowledge, the present study is the first to report that CD73 may also be a biomarker for clear cell RCC. All normal kidney samples did not express CD73, as determined by immunohistochemical staining. In addition, $48.4 \%$ of clear cell RCC and $42.9 \%$ of uroepithelial cell carcinoma tissues exhibited intense CD73 staining. Thus, the expression of CD73 is increased in RCC and may act as an important marker for RCC patients.

An increasing quantity of novel evidence has revealed that cancer stem cells (CSCs) may exist in RCC (33). However, few studies have focused on the identification of renal CSCs, and studies have been performed to investigate and verify initial markers on the cell surface of CSCs in RCC. The present study found that in vitro cultured and in vivo $\mathrm{RCC} \mathrm{CD} 73^{+}$cells possess a stronger tumorigenic capacity compared with $\mathrm{CD}^{-} 3^{-}$cells (data not shown). Therefore, a patent has been obtained for the use of CD73 as a renal clear cell carcinoma stem cell surface marker (34). CSCs, known for their resistance to chemotherapeutic agents and their tumor initiating ability (35), may exhibit distinct pro-angiogenic and micro vesicular properties and play relevant roles in the pathogenesis and prognosis of RCC tumors. Previous studies have hypothesized that well-differentiated cancer cells tend to produce a higher level of CD73 $(36,37)$. Since clear cell carcinoma and uroepithelium carcinoma mainly originate from the renal tubular epithelial and urinary tract epithelial cells, RCC CSCs possibly originate from mutated normal stem cells in the kidney and conserve the expression of CD73 during differentiation into endothelial cells.

A high level of CD73 expression is associated with a poor prognosis in colorectal cancer (38). However, the role of CD73 expression in cancer cells in determining the prognosis of patients remains controversial in breast cancer $(29,38-40)$, which may be due to the conversion of adenosine that is promoted by CD73 in tumors. In the present cohort of RCC patients, intense CD73 protein expression in cancer cells was associated with a 
A

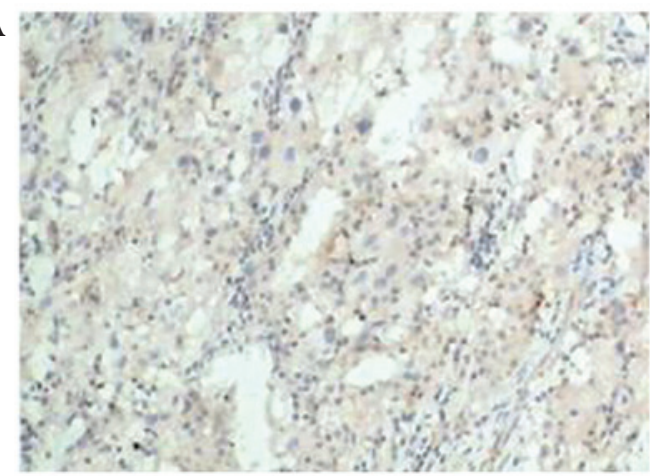

C

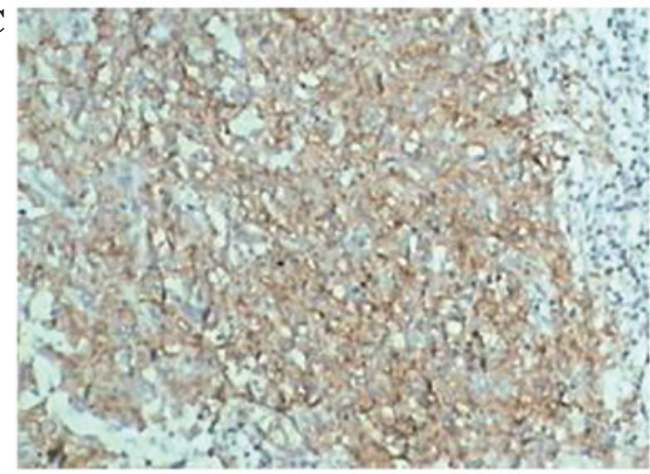

$\mathbf{E}$

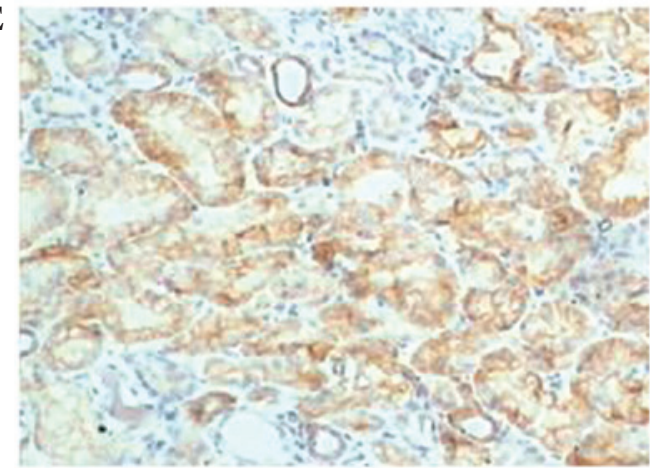

B

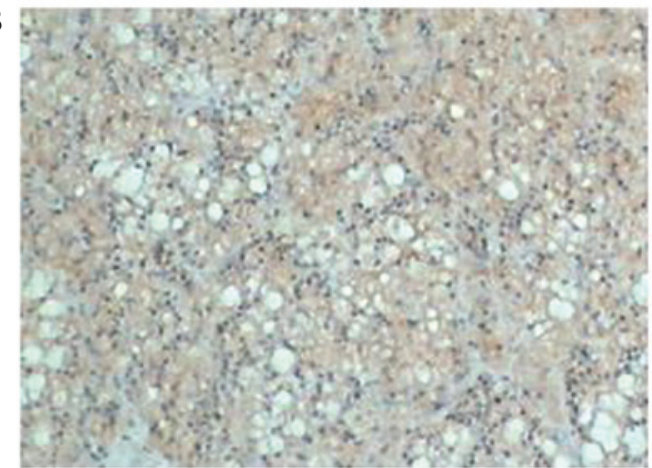

D
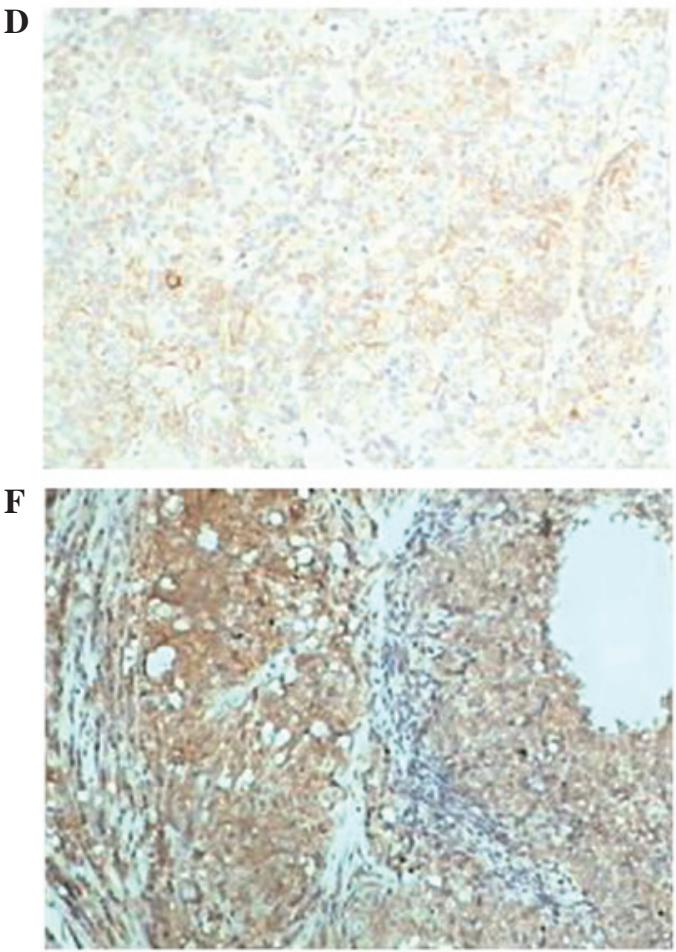

Figure 4. P-glycoprotein staining in RCC tissues using immunohistochemical staining. (A) Level 1 clear cell RCC tissue (magnification, $\mathrm{x} 100$ ). (B) Level 2 clear cell RCC tissue (magnification, x100). (C) Level 3 clear cell RCC tissues (magnification, x100). (D) Level 1 uroepithelial carcinoma tissue (magnification, x200). (E) Level 2 uroepithelial carcinoma tissues (magnification, x200). (F) Level 3 urothelial carcinoma tissue (magnification, x100).
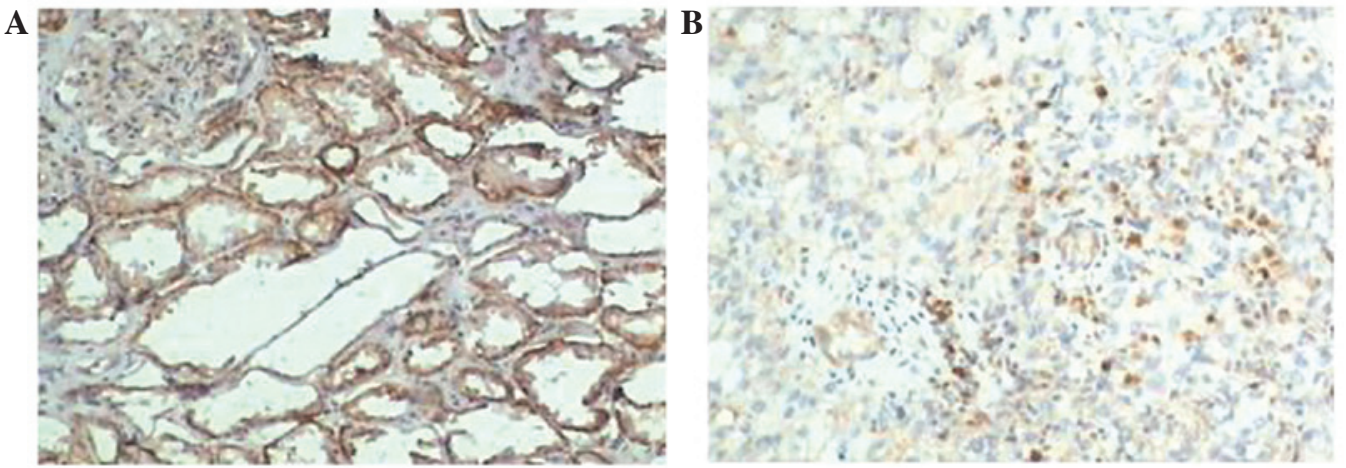

Figure 5. Immunohistochemical staining of P-glycoprotein in (A) glomeruli, tubules and (B) lymphocytes in renal cell carcinoma tissues (magnification, x200).

worse prognosis, increased tumor grade and increased TNM stage compared with cells that did not express CD73. Currently, the present results support that CD73-expressing RCC lesions are more aggressive compared with lesions that do not express CD73.
Inflammatory hypoxia (14), hypoxia inducible factor-1 (HIF-1) (41) and Wnt signaling $(42,43)$ are potent transcriptional stimuli for CD73 expression, which implies that the microenvironment of malignant tumors elevates CD73 expression. At present, it is challenging to estimate the 
relative contribution of cancer cells compared with other cells or exosomes that contribute to adenosine production in the tumor microenvironment in vivo. However, the majority of findings strongly indicate that CD73 functions at multiple levels in limiting antitumor effects (44).

Although the vascular expression of CD73 in RCC samples was not significantly different from that of normal renal cells, CD73 may play other roles in RCC progression. CD73 is known to participate in leukocyte extravasation from blood in endothelial cells and lymphatics (45) and to regulate endothelial hemostasis (46). In addition, CD73 overexpression may play a role in the immune system response (47) or also result from a selective pressure exerted by the immune system. Cells positive for CD73 through the production of immunosuppressive adenosine are more able to evade anti-tumor immune responses (48). These findings indicate that CD73 is associated with tumor proliferation, metastasis and invasion $(7,8,44,49)$. By contrast, the suppression of CD73 induces apoptosis and cell-cycle arrest in human breast cancer cells (50), and the inhibition of adenosine production by CD73 could be a therapeutic target for the prevention of tumor angiogenesis and metastasis (14). Therefore, although the association between CD73 and tumor progression requires further investigation, the present results indicate that CD73 is involved in tumor progression and is a potential target for tumor therapy.

$\mathrm{RCC}$ is resistant to antitumor drugs, implying high expression levels of membrane transport proteins that inhibit the cellular influx and increase the efflux of chemotherapeutic drugs. P-gp is a well-known plasma membrane drug efflux pump involved in the chemo resistance of numerous types of tumors $(7,8)$. However, the association between RCC and P-gp is disputed (9-13). In the present study, it was found that P-gp was mainly expressed on the blood vessels in RCC tissues, and was particularly associated with the tumor type and tumor grade. Normal human tissues from the majority of secretory organs have been analyzed for P-gp expression (51) and it has been found that in the normal kidney, P-gp is immunoreactive on the epithelial cells of the proximal tubules, but not within the capillaries of the glomerular tuft and endothelial cells of arterioles (52). The most notable observations have been found in the endothelial cells of capillary blood vessels at blood-tissue barrier sites, including in the central nervous system, papillary dermis and choroid plexus (53). Recently, the MDR1 C3435T-associated variable P-gp expression and function were also identified in peripheral blood mononuclear cells $(54,55)$. This indicates that the shifting expression of P-gp in blood vessels may have important implications in cancer chemotherapy and reinforced self-protection in $\mathrm{RCC}$. The present findings revealed that $\mathrm{P}$-gp expression in tumor vessels of clear cell RCC is associated with a worse tumor grade and poorer clinical treatment effect. The role of P-gp-mediated chemoresistance in RCC may therefore not change with the expression quantity, but the migration of P-gp to the blood vessels for recycling may strengthen the barrier function, exerting its cytotoxic action rapidly, prior to intrinsic resistance mechanisms being activated. In the present study, however, P-gp expression levels were not significantly associated with the prognosis of patients with RCC. Therefore, P-gp remains controversial as a prognostic biomarker for $\mathrm{RCC}$, but may be an important factor in the failure of treatment for RCC. Solidifying the role of P-gp in metastatic RCC in all patients may therefore continue to aid in optimizing treatment for RCC.

In the present study, it was found that the expression level of CD73 in RCC tumors was associated with the tumor stage, tumor grade and patient survival. The expression of CD73 in clear cell RCC tumor tissues was associated with a high tumor stage and tumor grade, but was associated with low patient survival, indicating the potential application of CD73 as a novel diagnostic and prognostic marker of clear cell RCC.

\section{Acknowledgements}

This study was supported by funding from the National Science Foundation of China (grant no., 30571860).

\section{References}

1. Jemal A, Siegel R, Ward E, Murray T, Xu J and Thun MJ: Cancer statistics, 2007. CA Cancer J Clin 57: 43-66, 2007.

2. Jemal A, Siegel R, Ward E, Hao Y, Xu J, Murray T and Thun MJ: Cancer statistics, 2008. CA Cancer J Clin 58: 71-96, 2008.

3. Hao X: Cancer epidemiology and prevention in China. Hua Xia Yi Yao 4: 335-339, 2009 (In Chinese).

4. Jemal A, Siegel R, Ward E, Hao Y, Xu J and Thun MJ: Cancer statistics, 2009. CA Cancer J Clin 59: 225-249, 2009.

5. Wein AJ, Kavoussi LR, Novick AC, Partin AW and Peters CA (eds): Campbell-Walsh Urology. 9th edition. Saunders Elsevier, Philadelphia, PA, 2007.

6. Beck SD, Patel MI, Snyder ME, et al: Effect of papillary and chromophobe cell type on disease-free survival after nephrectomy for renal cell carcinoma. Ann Surg Oncol 11: 71-77, 2004.

7. Wang L, Zhou X, Zhou T, et al: Ecto-5'-nucleotidase promotes invasion, migration and adhesion of human breast cancer cells. J Cancer Res Clin Oncol 134: 365-372, 2008.

8. Jin D, Fan J, Wang L, Thompson LF, Liu A, Daniel BJ, Shin T, Curiel TJ and Zhang B: CD73 on tumor cells impairs antitumor T-cell responses: A novel mechanism of tumor-induced immune suppression. Cancer Res 70: 2245-2255, 2010.

9. Naito S, Sakamoto N, Kotoh S, Goto K, Matsumoto T and Kumazawa J: Expression of P-glycoprotein and multidrug resistance in renal cell carcinoma. Eur Urol 24: 156-160, 1993.

10. Bak M Jr, Efferth T, Mickisch G, Mattern J and Volm M: Detection of drug resistance and P-glycoprotein in human renal cell carcinomas. Eur Urol 17: 72-75, 1990.

11. Hofmockel G, Bassukas ID, Wittmann A and Dämmrich J: Is the expression of multidrug resistance gene product a prognostic indicator for the clinical outcome of patients with renal cancer? Br J Urol 80: 11-17, 1997.

12. Kanamaru H, Kakehi Y, Yoshida O, Nakanishi S, Pastan I and Gottesman MM: MDR1 RNA levels in human renal cell carcinomas: Correlation with grade and prediction of reversal of doxorubicin resistance by quinidine in tumor explants. J Natl Cancer Inst 81: 844-849, 1989.

13. Rochlitz CF, Lobeck H, Peter S, Reuter J, Mohr B, de Kant E, Huhn D and Herrmann R: Multiple drug resistance gene expression in human renal cell cancer is associated with the histologic subtype. Cancer 69: 2993-2998, 1992.

14. Colgan SP, Eltzschig HK, Eckle T and Thompson LF: Physiological roles for ecto-5'-nucleotidase (CD73). Purinergic Signal 2: 351-360, 2006.

15. Shirley DG, Vekaria RM and Sévigny J: Ectonucleotidases in the kidney. Purinergic Signal 5: 501-511, 2009.

16. Henttinen T, Jalkanen S and Yegutkin GG: Adherent leukocytes prevent adenosine formation and impair endothelial barrier function by Ecto-5'-nucleotidase/CD73-dependent mechanism. J Biol Chem 278: 24888-24895, 2003.

17. Eckle T, Krahn T, Grenz A, Köhler D, Mittelbronn M, Ledent C, Jacobson MA, Osswald H, Thompson LF, Unertl $\mathrm{K}$, et al: Cardioprotection by ecto-5'-nucleotidase (CD73) and A2B adenosine receptors. Circulation 115: 1581-1590, 2007. 
18. Wu XR, He XS, Chen YF, Yuan RX, Zeng Y, Lian L, Zou YF, Lan N, Wu XJ and Lan P: High expression of CD73 as a poor prognostic biomarker in human colorectal cancer. J Surg Oncol 106: 130-137, 2012.

19. Supernat A, Markiewicz A, Welnicka-Jaskiewicz M, Seroczynska B, Skokowski J, Sejda A, Szade J, Czapiewski P, Biernat W and Zaczek A: CD73 expression as a potential marker of good prognosis in breast carcinoma. Appl Immunohistochem Mol Morphol 20: 103-107, 2012.

20. Grenz A, Zhang H, Eckle T, Mittelbronn M, Wehrmann M, Köhle C, Kloor D, Thompson LF, Osswald H and Eltzschig HK: Protective role of ecto-5'-nucleotidase (CD73) in renal ischemia. J Am Soc Nephrol 18: 833-845, 2007.

21. Eble JN, Togashi K and Pisani P: Renal cell carcinoma. In: Pathology and Genetics of Tumours of the Urinary System and Male Genital Organs. World Health Organization Classification of Tumors. Eble JN, Sauter G, Epstein JI and Sesterhenn IA (eds).IARC Press, Lyon, pp12-43, 2004.

22. Stella J, Bavaresco L, Braganhol E, Rockenbach L, Farias PF, Wink MR, Azambuja AA, Barrios CH, Morrone FB and Oliveira Battastini AM: Differential ectonucleotidase expression in human bladder cancer cell lines. Urol Oncol 28 260-267, 2010.

23. Mikhailov A, Sokolovskaya A, Yegutkin GG, et al: CD73 participates in cellular multiresistance program and protects against TRAIL-induced apoptosis. J Immunol 181: 464-475, 2008.

24. Bavaresco L, Bernardi A, Braganhol E, Cappellari AR, Rockenbach L, Farias PF, Wink MR, Delgado-Cañedo A and Battastini AM: The role of ecto-5'-nucleotidase/CD73 in glioma cell line proliferation. Mol Cell Biochem 319: 61-68, 2008.

25. Sadej R, Spychala J and Skladanowski AC: Ecto-5'-nucleotidase (eN, CD73) is coexpressed with metastasis promoting antigens in human melanoma cells. Nucleosides Nucleotides Nucleic Acids 25: 1119-1123, 2006

26. Cho SY, Polster J, Engles JM, Hilton J, Abraham EH and Wahl RL: In vitro evaluation of adenosine 5'-monophosphate as an imaging agent of tumor metabolism. J Nucl Med 47: $837-845,2006$

27. Serra S, Horenstein AL, Vaisitti T, Brusa D, Rossi D, Laurenti L, D'Arena G, Coscia M, Tripodo C, Inghirami G, et al: CD73-generated extracellular adenosine in chronic lymphocytic leukemia creates local conditions counteracting drug-induced cell death. Blood 118: 6141-6152, 2011.

28. Sadej R, Spychala J and Skladanowski AC: Expression of ecto-5'-nucleotidase (eN, CD73) in cell lines from various stages of human melanoma. Melanoma Res 16: 213-222, 2006.

29. Spychala J, Lazarowski E, Ostapkowicz A, Ayscue LH, Jin A and Mitchell BS: Role of estrogen receptor in the regulation of ecto-5'-nucleotidase and adenosine in breast cancer. Clin Cancer Res 10: 708-717, 2004.

30. Kondo T, Nakazawa T, Murata SI and Katoh R: Expression of CD73 and its ecto-5'-nucleotidase activity are elevated in papillary thyroid carcinomas. Histopathology 48: 612-614, 2006.

31. Fukuda K, Sakakura C, Miyagawa K, Kuriu Y, Kin S, Nakase Y, Hagiwara A, Mitsufuji S, Okazaki Y, Hayashizaki Y, et al: Differential gene expression profiles of radioresistant oesophageal cancer cell lines established by continuous fractionated irradiation. Br J Cancer 91: 1543-1550, 2004

32. Hastie C, Saxton M, Akpan A, Cramer R, Masters JR and Naaby-Hansen S: Combined affinity labelling and mass spectrometry analysis of differential cell surface protein expression in normal and prostate cancer cells. Oncogene 24: 5905-5913, 2005.

33. Lu J, Cui Y, Zhu J, He J, Zhou G and Yue Z: Biological characteristics of Rh123(high) stem-like cells in a side population of 786-O renal carcinoma cells. Oncol Lett 5: 1903-1908, 2013.

34. Zhou G, Wang J, Song L, et al: Application of renal clear cell carcinoma stem cell surface markers. China CN201310181801.8. Filed May 16, 2013; issued January 7, 2015.

35. Reya T, Morrison SJ, Clarke MF and Weissman IL: Stem cells, cancer, and cancer stem cells. Nature 414: 105-111, 2001.

36. Rackley RR, Lewis TJ, Preston EM, Delmoro CM, Bradley EL Jr, Resnick MI, Pretlow TP and Pretlow TG: 5'-nucleotidase activity in prostatic carcinoma and benign prostatic hyperplasia. Cancer Res 49: 3702-3707, 1989.
37. OhHK, Sin JI, Choi J,Park SH,Lee TS and Choi YS: Overexpression of CD73 in epithelial ovarian carcinoma is associated with better prognosis, lower stage, better differentiation and lower regulatory T cell infiltration. J Gynecol Oncol 23: 274-281, 2012.

38. Wu XR, He XS, Chen YF, Yuan RX, Zeng Y, Lian L, Zou YF, Lan $\mathrm{N}, \mathrm{Wu} \mathrm{XJ}$ and Lan P: High expression of CD73 as a poor prognostic biomarker in human colorectal cancer. J Surg Oncol 106: 130-137, 2012.

39. Supernat A, Markiewicz A, Welnicka-Jaskiewicz M, Seroczynska B, Skokowski J, Sejda A, Szade J, Czapiewski P, Biernat W and Zaczek A: CD73 expression as a potential marker of good prognosis in breast carcnoma. Appl Immunohistochem Mol Morphol 20: 103-107, 2012.

40. Leth-Larsen R, Lund R, Hansen HV, Laenkholm AV, Tarin D, Jensen ON and Ditzel HJ: Metastasis-related plasma membrane proteins of human breast cancer cells identified by comparative quantitative mass spectrometry. Mol Cell Proteomics 8: 1436-1449, 2009.

41. Synnestvedt K, Furuta GT, Comerford KM, Louis N, Karhausen J, Eltzschig HK, Hansen KR, Thompson LF and Colgan SP: Ecto-5'-nucleotidase (CD73) regulation by hypoxia-inducible factor-1 mediates permeability changes in intestinal epithelia. J Clin Invest 110: 993-1002, 2002.

42. Spychala J, Zimmermann AG and Mitchell BS: Tissue-specific regulation of the ecto-5'-nucleotidase promoter. Role of the camp response element site in mediating repression by the upstream regulatory region. J Biol Chem 274: 22705-22712, 1999.

43. Spychala J and Kitajewski J: Wnt and $\beta$-catenin signaling target the expression of ecto-5'-nucleotidase and increase extracellular adenosine generation. Exp Cell Res 296: 99-108, 2004.

44. Zhang B: CD73 promotes tumor growth and metastasis Oncoimmunology 1: 67-70,2012.

45. Ålgars A, Karikoski M, Yegutkin GG, Stoitzner P, Niemelä J, Salmi M and Jalkanen S: Different role of CD73 in leukocyte trafficking via blood and lymph vessels. Blood 117: 4387-4393, 2011.

46. Jalkanen S and Salmi M: VAP-1 and CD73, endothelial cell surface enzymes in leukocyte extravasation. Arterioscler Thromb Vasc Biol 28: 18-26, 2008.

47. Thompson LF, Ruedi JM, Glass A, Low MG and Lucas AH: Antibodies to 5'-nucleotidase (CD73), a glycosyl-phosphatidylinositol-anchored protein, cause human peripheral blood T cells to proliferate. J Immunol 143: 1815-1821, 1989.

48. Allard B, Turcotte M and Stagg J: CD73-generated adenosine: orchestrating the tumor-stroma interplay to promote cancer growth. J Biomed Biotechnol 2012: 485156, 2012.

49. Spychala J: Tumor-promoting functions of adenosine. Pharmacol Ther 87: 161-173, 2000.

50. Zhi X, Wang Y, Zhou X, Yu J, Jian R, Tang S, Yin L and Zhou P. RNAi-mediated CD73 suppression induces apoptosis and cell-cycle arrest in human breast cancer cells. Cancer Sci 101: 2561-2569, 2010

51. Thiebaut F, Tsuruo T, Hamada H, Gottesman MM, Pastan I and Willingham MC: Cellular localization of the multidrug-resistance gene product P-glycoprotein in normal human tissues. Proc Natl Acad Sci USA 84: 7735-7738, 1987.

52. Cordoncardo C, O'Brien JP, Casals D and Rittman-Grauert L: Multidrug-resistance gene (P-glycoprotein) is expressed byendothelial cells at blood-brain barrier sites. Med Sci 86: 695-698, 1989.

53. Mignogna C, Staibano S, Altieri V, De Rosa G, Pannone G, Santoro A, Zamparese R, D'Armiento M, Rocchetti R, Mezza E, et al: Prognostic significance of multidrug-resistance protein (MDR-1) in renal clear cell carcinomas: A five year follow-up analysis. BMC Cancer 6: 293-312, 2006.

54. Fellay J, Marzolini C, Meaden ER, Back DJ, Buclin T, Chave JP, Decosterd LA, Furrer H, Opravil M, Pantaleo G, et al; Swiss HIV Cohort Study: Response to antiretroviral treatment in HIV-1-infected individuals with allelic variants of the multidrug resistance transporter 1: A pharmacogenetics study. Lancet 359: 30-36, 2002

55. Hitzl M, Drescher S, van der Kuip H, Schäffeler E, Fischer J, Schwab M. Eichelbaum M and Fromm MF: The C3435T mutation in the human MDR1 gene is associated with altered efflux of the P-glycoprotein substrate rhodamine 123 from CD56+ natural killer cells. Pharmacogenetics 11: 293-298, 2001. 